\title{
FAKTOR-FAKTOR YANG MEMPENGARUHI KEJADIAN DIARE PADA BALITA
}

\author{
Rahayu Setyaningsih, Diyono \\ STIKES PANTI KOSALA SURAKARTA, Sukoharjo, Jawa Tengah, Indonesia
}

\begin{abstract}
Abstrak
Latar Belakang. Berdasarkan data dari Profil Kesehatan Provinsi Jawa Tengah tahun 2017, proporsi kasus diare yang ditangani di Jawa Tengah tahun 2017 sebesar 55,8\%, kejadian diare yang tertangani tertinggi di Kabupaten Magelang, Surakarta dan Sukoharjo. Faktor-faktor yang mempengaruhi terjadinya diare antara lain status gizi, sosial ekonomi, informasi kesehatan, sosial budaya, sanitasi makanan, alergi dan infeksi saluran pencernaan.

Tujuan Penelitian. Mencari faktor-faktor yang mempengaruhi kejadian diare pada balita. Subjek dan Metode. Populasi ibu-ibu dan balita di Posyandu Desa Kadilangu dengan jumlah 57 sampel. Metode non eksperimen dengan pendekatan korelasi. Data dikumpulkan dengan menggunakan kuesioner, dianalisa menggunakan Chi Square.

Hasil Penelitian. Semua faktor mempengaruhi kejadian diare yaitu status gizi $(p=0,046)$, sanitasi makanan $(p=0,001)$, sosial ekonomi $(p=0,001)$ dan informasi kesehatan $(p=0,001)$.

Kesimpulan. Ada hubungan antara status gizi, sanitasi makanan, sosial ekonomi dan informasi kesehatan dengan kejadian diare.

Kata kunci: diare, informasi kesehatan, sanitasi, sosial ekonomi, status gizi
\end{abstract}

\section{THE FACTORS THAT INFLUENCE THE EVENT OF DIARRHEA ON TODLER}

\section{Rahayu Setyaningsih, Diyono}

\begin{abstract}
Background. Based on data from the Health Profile of Central Java Province on 2017, the proportion of diarrhea cases handled in Central Java in 2017 was 55.8\%, the highest incidence of diarrhea was handled in Magelang, Surakarta and Sukoharjo. Factors that influence the occurrence of diarrhea include nutritional status, socioeconomic, health information, socio-culture, food sanitation, allergies and digestive tract infections.

Research Objective. To find the factors that influence the incidence of diarrhea.

Subjects and Methods. Subject Population of mothers and toddlers, in Posyandu Kadilangu Village with 57 samples. Method is non-experimental research with correlation approach. Data were collected using a questionnaire, analyzed using chi square. Results. All factors are influence diarhhea, nutritional status $(p=0.046)$, food sanitation $(p=0.001)$, socioeconomic $(p=0.001)$ and health information $(p=0.001)$.

Conclusion. There is a relationship between nutritional status, food sanitation, socioeconomic and health information with the incidence of diarrhea.
\end{abstract}

Keywords: diarrhea, health information, nutritional status, sanitation, social economic

Korespondensi: Rahayu Setyaningsih. STIKES PANTI KOSALA SURAKARTA. Jalan Raya Solo - Baki KM. 4 Gedangan, Grogol, Sukoharjo, Jawa Tengah.

Email: rahayusetyaningsih78@gmail.com 
LATAR BELAKANG

Angka kejadian diare pada balita dari tahun ke tahun semakin meningkat. Laporan World Health Organization (WHO, 2010) menyatakan hampir 1,5 juta anak meninggal dunia setiap tahunnya karena diare. Berdasarkan data Riskesdas tahun 2013 insiden diare di Jawa Tengah pada usia balita sebanyak $6,5 \%$ dan menduduki posisi ke 13 dari 33 provinsi yang ada di Indonesia. Berdasarkan data dari Profil Kesehatan Provinsi Jawa Tengah (2017), proporsi kasus diare yang ditangani di Jawa Tengah tahun 2017 sebesar 55,8\%, menurun bila dibandingkan proporsi tahun 2016 yaitu 68,9\%. Kejadian diare yang tertangani tertinggi di Kabupaten Magelang dengan presentasi $175 \%$ sedangkan kota Surakarta sebanyak $79,2 \%$ dan Sukoharjo $54,3 \%$.

Faktor-faktor yang mempengaruhi terjadinya diare antara lain status gizi, sosial ekonomi, informasi kesehatan, sosial budaya, sanitasi makanan, alergi dan infeksi saluran pencernaan (Ariani, 2016). Menurut survei peneliti di Posyandu Desa Kadilangu jumlah balita yang tercatat dalam dokumen bidan desa dari 3 posyandu masing-masing kurang lebih setiap posyandu terdiri atas 2530 balita, dalam periode 3 bulan terakhir yang menderita diare sekitar 32 anak balita.

\section{TUJUAN PENELITIAN}

Untuk mengetahui hubungan status gizi, sanitasi makanan, sosial ekonomi dan informasi kesehatan dengan kejadian diare pada anak balita.

\section{METODE}

Penelitian ini merupakan penelitian analitik observasional dengan rancangan cross sectional dan desain korelasi. Instrumen penelitian yang digunakan adalah kuesioner dan data dianalisis menggunakan uji Chi Square.

\section{SUBJEK}

Subyek penelitian ini adalah ibu dengan balita di Posyandu Desa Kadilangu sejumlah 57 orang dan teknik sampling yang digunakan adalah total sampling.

HASIL

Karakteristik orangtua dan anak disajikan dalam tabel berikut ini:

Tabel 1.

Karakteristik Orangtua

\begin{tabular}{ccc}
\hline Karakteristik & $\mathrm{f}$ & $\%$ \\
\hline Umur (tahun) & & \\
$25-30$ & 23 & 40,4 \\
$31-35$ & 29 & 50,8 \\
$36-40$ & 5 & 8,8 \\
Pendidikan & & \\
Dasar & 4 & 7,0 \\
Menengah & 30 & 52,6 \\
Tinggi & 23 & 40,4 \\
\hline
\end{tabular}

Tabel 1 menunjukkan karakteristik orang tua responden mayoritas umur $31-35$ tahun $(50,8 \%)$ dengan mayoritas tingkat pendidikan adalah menengah $(52,6 \%)$.

Tabel 2.

Karakteristik Anak

\begin{tabular}{ccc}
\hline Karakteristik & $\mathrm{f}$ & $\%$ \\
\hline Umur (tahun) & & \\
$<1$ & 5 & 8,7 \\
$1-3$ & 40 & 70,2 \\
$4-5$ & 12 & 21,1 \\
Jenis Kelamin & & \\
Laki-Laki & 33 & 57,9 \\
Perempuan & 24 & 42,1 \\
\hline
\end{tabular}

Tabel 2 menunjukkan karakteristik anak yaitu mayoritas umur 1-3 tahun $(70,2 \%)$ dengan mayoritas jenis kelamin adalah laki-laki $(57,9 \%)$. 
Tabel 3.

Distribusi Frekuensi Status Gizi, Sanitasi Makanan, Sosial Ekonomi, Informasi Kesehatan dan Diare

\begin{tabular}{lcc}
\hline Karakteristik & $\mathrm{f}$ & $\%$ \\
\hline Status Gizi & 30 & 52,6 \\
Baik & 27 & 47,4 \\
Kurang & & \\
Sanitasi makanan & 26 & 45,6 \\
Baik & 31 & 54,4 \\
Kurang & & \\
Sosial ekonomi & 28 & 49,1 \\
Cukup & 29 & 50,9 \\
Tidak & & \\
Informasi kesehatan & 27 & 47,4 \\
Optimal & 30 & 52,6 \\
Kurang & & \\
Diare & 37 & 64,9 \\
Ya & 20 & 35,1 \\
\hline Tidak & & \\
\hline
\end{tabular}

Tabel 3 diketahui sebagian besar responden status gizinya baik yaitu $30(52,6 \%)$, sebagian besar sanitasi makanan kurang yaitu sebanyak 31 $(54,4 \%)$, sebagian besar sosial ekonomi adalah cukup yaitu sebesar
$28 \quad(49,1 \%)$, sebagian besar memperoleh informasi kurang optimal yaitu sebanyak $30(52,6 \%)$, sebagian besar responden mengalami diare dalam dua bulan terakhir yaitu sebesar $37(64,9 \%)$.

Tabel 4.

Tabulasi Silang Status Gizi, Sanitasi Makanan, Sosial Ekonomi dan Informasi Kesehatan dengan Diare

\begin{tabular}{|c|c|c|c|c|c|}
\hline \multirow[b]{2}{*}{ Variabel } & \multirow[b]{2}{*}{ Kategori } & \multicolumn{2}{|c|}{ Diare } & \multirow{2}{*}{$\begin{array}{c}\text { Jumlah } \\
(\%)\end{array}$} & \multirow[b]{2}{*}{$p$} \\
\hline & & $\begin{array}{l}\mathrm{Ya} \\
(\%)\end{array}$ & $\begin{array}{c}\text { Tidak } \\
(\%)\end{array}$ & & \\
\hline \multirow[t]{2}{*}{ Status Gizi } & Baik & $\begin{array}{c}23 \\
(767)\end{array}$ & $\begin{array}{c}7 \\
(233)\end{array}$ & $\begin{array}{c}30 \\
(100)\end{array}$ & 0,046 \\
\hline & Kurang & $\begin{array}{c}14 \\
(51,9)\end{array}$ & $\begin{array}{c}13 \\
(48,1)\end{array}$ & $\begin{array}{c}27 \\
(100)\end{array}$ & \\
\hline \multirow[t]{2}{*}{ Sanitasi Makanan } & Baik & $\begin{array}{c}11 \\
(42,3)\end{array}$ & $\begin{array}{c}15 \\
(57,7)\end{array}$ & $\begin{array}{c}26 \\
(100)\end{array}$ & 0,001 \\
\hline & Kurang & $\begin{array}{c}26 \\
(83,9)\end{array}$ & $\begin{array}{c}5 \\
(16,1)\end{array}$ & $\begin{array}{c}31 \\
(100)\end{array}$ & \\
\hline \multirow[t]{2}{*}{ Sosial Ekonomi } & Cukup & $\begin{array}{c}10 \\
(35,7)\end{array}$ & $\begin{array}{c}18 \\
(64,3)\end{array}$ & $\begin{array}{c}28 \\
(100)\end{array}$ & 0,001 \\
\hline & Tidak Cukup & $\begin{array}{c}27 \\
(93,1)\end{array}$ & $\begin{array}{c}2 \\
(6,9)\end{array}$ & $\begin{array}{c}29 \\
(100)\end{array}$ & \\
\hline \multirow[t]{2}{*}{ Informasi Kesehatan } & Optimal & $\begin{array}{c}11 \\
(40,7)\end{array}$ & $\begin{array}{c}16 \\
(59,3)\end{array}$ & $\begin{array}{c}27 \\
(100)\end{array}$ & 0,001 \\
\hline & Kurang & $\begin{array}{c}26 \\
(86,7)\end{array}$ & $\begin{array}{c}4 \\
(13,3)\end{array}$ & $\begin{array}{c}30 \\
(100)\end{array}$ & \\
\hline
\end{tabular}


Tabel 4 menunjukkan terdapat hubungan status gizi dengan kejadian diare $(p=0,046)$, sanitasi makanan dengan kejadian diare $(p=0,001)$, sosial ekonomi dengan kejadian diare $(p=0,001)$ dan informasi kesehatan dengan kejadian diare $(p=0,001)$.

\section{PEMBAHASAN}

Pada variabel status gizi diperoleh informasi bahwa terdapat 30 responden dengan status gizi baik yang mengalami diare sebanyak 23 $(76,7 \%), 27$ responden dengan status gizi kurang mengalami diare sebanyak 14 (51,9\%). Status gizi mempunyai keterkaitan yang erat dengan kejadian infeksi. Anak yang mempunyai status gizi kurang, akan mudah terkena infeksi karena anak tidak mempunyai daya tahan tubuh yang cukup. Sebaliknya, anak yang menderita infeksi, umumnya tidak mempunyai nafsu makan yang cukup, akibatnya anak kekurangan gizi dan jatuh pada status gizi kurang. Jadi keterkaitan infeksi dengan status gizi mempunyai hubungan timbal balik yang kuat (Par'i, 2019). Makin buruk gizi seorang anak, ternyata makin banyak episode diare yang dialami. Pada anak dengan malnutrisi, kelenjar timusnya akan mengecil dan kekebalan sel-sel menjadi terbatas sekali sehingga kemampuan untuk mengadakan kekebalan nonspesifik terhadap kelompok organisme berkurang (Lestari, 2016). Beberapa penyakit infeksi yang terkait dengan status gizi adalah diare, TBC, cacingan, campak, batuk rejan, dan penyakit infeksi lainnya. Pengaruh keadaan gizi pada kelompok umur 1-4 tahun lebih besar dibandingkan dengan kelompok umur kurang dari 1 tahun. Umur anak terbanyak pada penelitian ini adalah 1-3 tahun yaitu sebanyak 40 orang. Masalah utamanya disebabkan oleh asupan gizi tidak cukup dan anak mudah terkena penyakit infeksi karena anak bermain pada tempat yang kotor. Selain itu, anak mudah stres karena baru disapih. Pada usia ini anak sedang tumbuh pesat, sementara asupan gizi kurang maka balita bisa menderita KEP dan defisiensi gizi yang lain (Par'i, 2019). Kurang gizi mengganggu perkembangan mental dan fisik serta menghambat potensi roh seorang anak sebagai manusia. WHO menyebutkan anak-anak yang memiliki berat badan kurang lebih beresiko terhadap kematian. Pengaruh kurang gizi pada kematian anak di bawah 5 tahun di negara berkembang akibat dari penyakit diare menyumbang angka sebesar $5 \%$ (Sodikin, 2012). Berdasarkan hasil uji statistik bivariat dengan menggunakan Chi Square diketahui $p=0,046$, yaitu terdapat hubungan antara status gizi dengan diare. Hal ini sejalan dengan penelitian Nurdin, Rau dan Timumun (2015), bahwa ada hubungan antara status gizi dengan kejadian diare $(p=0,003)$, buruknya status gizi anak mempengaruhi lamanya diare dan komplikasi yang diderita, status gizi yang buruk juga meningkatkan terjadinya dehidrasi pada anak yang mengalami diare. Gizi yang kurang juga memudahkan anak untuk terinfeksi, hal ini disebabkan karena terganggunya pembentukan kekebalan, terganggunya sel granulosit dan berkurangnya kadar komplemen. Penelitian Nurbaya (2018), juga menunjukkan hal yang sama, dengan kesimpulan ada hubungan status gizi dengan diare $(p=0,008)$, semakin buruk status gizi balita semakin beresiko pula terjadi diare, status gizi yang baik sangat dibutuhkan oleh balita karena apabila balita mengalami kekurangan gizi akan membuat kekebalan sel menjadi terbatas sekali sehingga kemampuan untuk mengadakan kekebalan non spesifik 
terhadap kelompok organisme berkurang.

Pada variabel sanitasi makanan diperoleh keterangan terdapat 26 responden dengan sanitasi makanan baik, mengalami diare sebanyak $11(42,3 \%), 31$ responden dengan sanitasi makanan kurang baik, mengalami diare sebanyak 26 $(83,9 \%)$. Sanitasi makanan adalah pencegahan yang menitikberatkan pada kegiatan dan tindakan yang perlu untuk membebaskan makanan dan minuman dari segala bahaya yang dapat mengganggu kesehatan mulai dari sebelum makanan diproses, selama dalam proses pengolahan, penyimpanan, pengangkutan, penyajian sampai pada makanan dan minuman itu dikonsumsi. Kebersihan dalam penyiapan, proses dan penyajian makanan menjadi hal sangat berpengaruh terhadap terjadinya diare. Seperti diketahui bahwa penyebab diare antara lain karena faktor infeksi, malabsorbsi, makanan dan minuman yang dikonsumsi dan faktor terhadap laktosa (susu kaleng). Dari faktor makanan dan minuman seperti makanan basi, beracun, alergi terhadap makanan dan minuman. Kontak antara sumber dan host dapat terjadi melalui air, terutama air minum yang tidak dimasak, dapat juga terjadi sewaktu mandi dan berkumur. Sanitasi makanan yang tidak baik kemungkinan disebabkan karena kurangnya kesadaran dari orangtua untuk menjaga kebersihan makanan keluarganya, seperti mencuci peralatan makan tidak bersih, cara menyajikan dan menyimpan makanan di atas meja dalam keadaan terbuka tanpa ditutup, hal ini menyebabkan makanan terkontaminasi oleh bakteri, yang kemudian dikonsumsi oleh keluarga, pada akhirnya menimbulkan gejala diare terutama pada balita. Bakteri yang terdapat pada saluran pencernaan adalah bakteri
Entamoeba Colli, Salmonella, Shigella. Dari faktor infeksi virus, penyebab diare terbanyak adalah Rotavirus, Adenovirus, Enterovirus, Astrovirus, Minirotavirus dan Calicivirus. Virus masuk ke dalam tractus digestivus bersama makanan dan minuman, kemudian berkembangbiak di dalam usus terutama di epitel usus halus yang menyebabkan kerusakan bagian apikal vili usus halus. Bagian yang rusak ini akan digantikan oleh selsel bagian kripta yang belum matang, berbentuk kuboid atau gepeng. Akibatnya sel-sel ini tidak dapat berfungsi untuk menyerap air dan makanan, sehingga terjadilah diare osmotik (Ariani, 2016). Pada diare yang penyebabnya karena sanitasi makanan maka perlu memperbaiki cara penyiapan dan penyimpanan makanan untuk mengurangi paparan dari perkembangbiakan bakteri (Sodikin, 2011). Berdasarkan hasil uji statistik bivariat dengan menggunakan Chi Square diperoleh $p=0,001$, terdapat hubungan antara sanitasi makanan dengan diare. Hal ini sesuai dengan penelitian Karyo (2014), diperoleh kesimpulan terdapat hubungan antara sanitasi makanan dengan kejadian diare pada balita. Sanitasi makanan yang baik dalam hal pemilihan makanan sampai dengan penyajian menghindarkan penyakit diare dari balita. Sejalan juga dengan penelitian Hasifah (2018) diperoleh hasil bahwa ada hubungan antara sanitasi makanan dan kepemilikan jamban dengan kejadian diare $(p=0,000)$. Perilaku kesehatan yang baik sangat membantu dalam proses pencegahan kejadian diare. Hal ini harus diikuti dengan kesadaran diri dengan membiasakan mencuci bersih makanan sebelum diolah, menyimpan makanan tidak terlalu lama dan pada suhu tertentu, menyimpan makanan yang sudah 
diolah dengan wadah yang mempunyai penutup serta mencuci alat masak sebelum digunakan.

Pada variabel sosial ekonomi terdapat 28 responden dengan sosial ekonomi cukup, mengalami diare sebanyak $10(35,7 \%), 29$ responden dengan sosial ekonomi kurang, mengalami diare sebanyak $27(93,1 \%)$. Keluarga dengan sosial ekonomi yang cukup dalam penelitian ini adalah pendapatan keluarga di atas UMK maka akan mampu untuk mencukupi kebutuhan sehari-hari. Indikator besar kecilnya pendapatan dapat dilihat dari standar upah minimum. Upah Minimum Kabupaten (UMK) Kabupaten Sukoharjo tahun 2020 adalah $\mathrm{Rp}$ 1.938.000 (Indozone, 2020). Penetapan Upah Minimum didasarkan pada Kebutuhan Hidup Layak (KHL) dengan memperhatikan produktivitas dan pertumbuhan ekonomi. Komponen kebutuhan hidup layak digunakan sebagai dasar penentuan Upah Minimum, dimana dihitung berdasarkan kebutuhan hidup pekerja dalam memenuhi kebutuhan mendasar yang meliputi kebutuhan akan pangan 2100 kkal perhari, perumahan, pakaian, pendidikan dan sebagainya artinya apabila pendapatan di bawah upah minimum dianggap sebagai pendapatan rendah (Kompas, 2019). Apabila pendapatan yang diperoleh keluarga memadai atau cukup maka keluarga tersebut akan mampu memenuhi kebutuhan pangan, sandang dan papan, tidak hanya mampu untuk menyediakan tetapi juga memenuhi syarat kesehatan. Anak akan mendapatkan asupan gizi dengan menu yang bervariasi, pakaian yang bersih dan nyaman, lingkungan tempat tinggal yang aman dan bersih. Berdasarkan hasil uji statistik bivariat dengan menggunakan Chi Square $p=0,001$ terdapat hubungan antara sosial ekonomi dengan diare. Hal ini sejalan dengan penelitian Amalya (2010), penghasilan keluarga menunjukkan adanya hubungan sosial ekonomi dengan kejadian diare, jika penghasilan meningkat maka yang dibeli bisa bervariasi, keluarga yang berpendapatan rendah memiliki keterbatasan dalam usaha pencegahan penyakit dan pemanfaatan sarana kesehatan. Hal ini juga sejalan dengan penelitian Ariesta, Ervina dan Aida (2016), dengan kesimpulan ada hubungan sosial ekonomi dengan kejadian diare pada balita $(p=0,006)$, pendapatan yang diperoleh ibu dapat digunakan untuk perbaikan pangan anggota keluarga sehingga kebutuhan pangan terpenuhi dan terhindar dari kekurangan gizi yang berdampak pada sistem kekebalan tubuh anggota keluarga.

Pada variabel informasi kesehatan terdapat 27 responden dengan informasi kesehatan optimal, mengalami diare sebanyak 11 $(40,7 \%), \quad 30$ responden dengan informasi kesehatan kurang, mengalami diare sebanyak 26 $(86,7 \%)$. Menurut Green dalam Notoatmojo (2010), menganalisis perilaku manusia dari tingkat kesehatan, kesehatan seseorang atau masyarakat dipengaruhi salah satunya faktor pendorong (reinforcing factor) yang terwujud dalam sikap dan perilaku petugas kesehatan atau petugas lain yang merupakan kelompok referensi dari perilaku masyarakat mengenai informasi kesehatan, hal ini mendukung bahwa informasi bisa dikatakan sebagai pengetahuan yang didapatkan dari pembelajaran, pengalaman atau instruksi yang bersumber dari pelayanan kesehatan ataupun media elektronik yang sangat mempengaruhi kesehatan. Pengetahuan ibu yang rendah serta kurangnya pemahaman ibu terhadap informasi yang telah diberikan menjadi pemicu terjadinya diare. Dari hasil penelitian 
diperoleh sebanyak 30 responden mendapatkan informasi kesehatan hanya dari 1 atau 2 sumber, sehingga arus informasi yang masuk kemungkinan kurang memenuhi kebutuhan pengetahuan sehingga mempengaruhi perilaku kesehatan dari individu. Perlu adanya pemberdayaan dari masyarakat supaya mereka mau menggali informasi untuk meningkatkan pengetahuan sehingga derajat kesehatan masyarakat meningkat. Pemberdayaan masyarakat dalam hal ini adalah menumbuhkan kesadaran, kemauan, dan kemampuan masyarakat agar dapat mengenali, mengatasi, memelihara, melindungi dan meningkatkan kesejahteraan dan kualitas kesehatan mereka sendiri (Induniasih dan Ratna, 2017). Apabila pemberdayaan masyarakat bisa berjalan dengan baik maka masyarakat secara mandiri mempunyai kemampuan untuk mengidentifikasi masalah, perencanaan dan pelaksanaan pemecahan masalah yang tentunya dengan memanfaatkan potensi yang dimiliki tanpa tergantung dengan bantuan pihak lain. Informasi kesehatan yang diperlukan oleh masyarakat diantaranya adalah tentang penyakit baik yang menular atau tidak menular, makanan yang bergizi yang dapat menunjang kesehatan, sanitasi dan lingkungan yang sehat. Informasi yang benar tentang diare dari berbagai sumber atau media yang bisa diakses oleh responden dengan sendirinya akan meningkatkan pengetahuan sehingga mereka bisa melakukan tindakan pencegahan diare dengan baik. Berdasarkan hasil uji statistik bivariat dengan menggunakan Chi Square $p=0,001$, terdapat hubungan antara informasi kesehatan dengan diare. Penelitian ini sesuai dengan penelitian Meliyanti (2016), diperoleh kesimpulan ada hubungan antara informasi kesehatan dengan kejadian diare $(p$ value $=0,001)$. Sejalan juga dengan penelitian Kirana (2018), faktor resiko yang ikut berperan pada kejadian diare adalah karena kurang pengetahuan ibu akibat kurangnya informasi kesehatan tentang hal-hal yang dapat menimbulkan diare terutama $4 \mathrm{~F}$ yaitu Finger, Food, Feces dan Fly. Memberikan contoh yang baik kepada anak seperti mencuci tangan dengan sabun dan air mengalir setelah buang air besar, buang air kecil, sebelum dan sesudah makan, setelah bermain merupakan hal yang harus orangtua lakukan untuk mengurangi pertumbuhan dan perkembangan bakteri yang ada di tangan.

\section{KESIMPULAN}

Banyak faktor yang mempengaruhi kejadian diare pada balita, pada penelitian ini faktor yang mempengaruhi diantaranya adalah status gizi, sanitasi makanan, sosial ekonomi dan informasi kesehatan.

\section{SARAN}

Disarankan orangtua untuk menjaga status gizi anak supaya tidak terjadi diare, dengan cara memberikan makanan yang bergizi kepada anak balita secara konsisten, memperhatikan kebersihan makanan selama penyiapan, pengolahan dan penyajian makanan, mencari informasi kesehatan dari berbagai sumber untuk mendukung pengetahuan tentang kesehatan terutama diare. Bagi tenaga kesehatan diharapkan terus memberikan motivasi dan pengetahuan kesehatan kepada masyarakat melalui berbagai cara dan media yang menarik.

\section{DAFTAR PUSTAKA}

Amalya, L. 2010. "Hubungan Faktor Lingkungan dan Sosial Ekonomi dengan Kejadian Diare pada Balita di Kelurahan Pisangan Ciputat Timur Bulan 
Agustus 2010." Jurnal Universitas Islam Negeri Syarif Hidayatullah. Diakses tanggal 18 April 2020.

Ariani, A. P. 2016. Diare Pencegahan dan Pengobatannya. Nuha Medika, Yogyakarta.

Ariesta, R., A. Ervina dan D. N. Aida. 2016. "Hubungan Sosial Ekonomi Keluarga dan Pekerjaan Ibu dengan Kejadian Diare pada Balita." Jurnal Obstretika Scientia. Diakses tanggal 20 April 2020.

Dinas Kesehatan Privinsi Jawa Tengah. 2017. Profil Kesehatan Provinsi Jawa tengah 2017. Semarang.

Hasifah. 2018. "Hubungan Sanitasi Makanan dan Jamban Keluarga dengan Kejadian Diare di Wilayah Kerja Puskesmas Bontonompo I Kabupaten Gowa." Jurnal IImiah Kesehatan. Diakses tanggal 20 April 2020.

Indozone. 2020. Rincian Lengkap UMP dan UMK Pulau Jawa Tahun 2020. Diakses tanggal 18 April 2020.

Induniasih dan W. Ratna. 2017. Promosi Kesehatan Pendidikan Kesehatan dalam Keperawatan. Pustaka Baru Press, Yogyakarta.

Karyo. 2014. "Hubungan antara Sanitasi Makanan dengan Kejadian Diare pada Balita di Desa Sokosari Kecamatan Soko Kabupaten Tuban." ejournal STIKES NU Tuban. Diakses tanggal 14 April 2020.

Kirana, N. 2018. "Hubungan antara Faktor Predisposisi pada lbu terhadap Kejadian Diare pada Balita." Jurnal Promkes. Diakses tanggal 22 April 2020.

Kompas. 2019. Rincian UMK Jawa Tengah 2020. Diakses tanggal 25 April 2020.
Lestari, T. 2016. Asuhan Keperawatan Anak. Nuha Medika, Yogyakarta.

2016. "Faktor-Faktor yang Berhubungan dengan Kejadian Diare pada Balita." Jurnal IImu Kesehatan Aisyah. Diakses tanggal 18 April 2020.

Meliyanti, F. 2016. "Faktor-faktor yang Berhubungan dengan Kejadian Diare pada Balita". Jurnal IImu Kesehatan Aisyah. Vol. 1. No. 2. Stikes Aisyah Pringsewu Lampung. Diakses pada tanggal 27 Februari 2019.

Notoatmojo, S. 2010. IImu Perilaku Kesehatan. Rhineka Cipta, Jakarta.

Nurbaya, S. 2018. "Hubungan Status Gizi dengan Kejadian Diare pada Balita Umur 3-5 Tahun di Rumah Sakit TK II Pelamonia Makasar." Jurnal IImiah Kesehatan Diagnosis. Diakses tanggal 21 April 2020.

Nurdin, N., M.J. Rau dan N.S.C.J.P. Timumun. 2015. "Hubungan antara Pemberian ASI Eksklusif dan Status Gizi dengan Kejadian Diare pada Anak Usia 6-24 Bulan di Kelurahan Tatuta Utara Palu." Jurnal Kesehatan Masyarakat : Preventif. Diakses tanggal 22 April 2020.

Par'i, H.M. 2019. Penilaian Status Gizi. Jakarta : Penerbit Buku Kedokteran, EGC.

Sodikin. 2012. Keperawatan Anak Gangguan Pencernaan. Jakarta: EGC.

2011. Asuhan Keperawatan Anak Gangguan sistem Gastrointestinal dan Hepatobilier. Salemba Medika, Jakarta.

World Health Organization. 2010. Global Situation and Trend. http://who.int/gha/diarrhea/en/.

Diakses pada tanggal 5 Januari 2020. 